\title{
Recent plate re-organization at the Azores Triple Junction: Evidence from combined geochemical and geochronological data on Faial, S. Jorge and Terceira volcanic islands
}

\author{
Anthony Hildenbrand ${ }^{\mathrm{a}, \mathrm{b}, *}$, Dominique Weis ${ }^{c}$, Pedro Madureira ${ }^{\mathrm{d}, \mathrm{e}}$, Fernando Ornelas Marques ${ }^{\mathrm{f}}$ \\ a Univ Paris-Sud, Laboratoire GEOPS, UMR8148, Orsay, F-91405, France \\ b CNRS, Orsay, F-91405, France \\ c Pac fic Center for Isotope and Geochemical Research, Department of Earth, Ocean and Atmospheric Sciences, University of British Columbia, 2020-2207 Main Mall, Vancouver, BC V6T1Z4, Canada \\ d Estrutura de Missão para a Extensão da Plataforma Continental, R. Costa Pinto, 165, 2770-047, Paço D'Arcos, Portugal \\ e Centro de Geofisica de vora and Dep. de Geocincias da Univ. de vora, R. Romão Ramalho, 59, 7000-671 vora, Portugal \\ ${ }^{\mathrm{f}}$ Universidade de Lisboa, Lisboa, Portugal
}

\section{a r t icle info}

\section{Article history:}

Received 30 March 2014

Accepted 14 September 2014

Available online 22 October 2014

\section{Keywords:}

Azores Triple Junction

Geochemistry

$\mathrm{K} / \mathrm{Ar}$ dating

Melt production

Mantle fertility

Lithospheric deformation

\begin{abstract}
a b s t r a c t
The study of volcanism near unstable plate triple junctions (TJs) offers a unique opportunity to investigate the interactions between mantle dynamics and lithospheric deformation in relation to short-term plate reconfiguration. From combined geochronological and geochemical analyses on Terceira, S. Jorge and Faial volcanic islands, we evidence contrasted modes of melt generation near the Azores Triple Junction during the last 1.3 Myr. The oldest lavas ( N800 ka) erupted along N150 elongated volcanic systems in S. Jorge and Faial have homogeneous isotopic compositions which partly overlap the compositional field of MORBs from the adjacent Mid-Atlantic Ridge (MAR). In contrast, the younger lavas (b750 ka) erupted along the N110 main structural direction on the three islands are significantly more enriched in LILE and LREE, and have more variable and generally more radiogenic $\mathrm{Sr}, \mathrm{Pb}, \mathrm{Nd}$ and $\mathrm{Hf}$ isotopic ratios. Altogether, our data do not support the presence of an active mantle plume under the central Azores. Instead, they suggest that magma generation results from decompression melting of a heterogeneously fertilized mantle (fossil plume?). The higher geochemical heterogeneity of the lavas erupted during the last $750 \mathrm{kyr}$ likely reflects low-degree partial melting promoted by recent reactivation of pre-existing MAR Fracture Zones. We propose that the sub-aerial volcanism over the last $1.3 \mathrm{Myr}$ in the central Azores records a sudden change in the conditions of melt generation, due to a major reconfiguration in regional deformation associated with the recent reorganization of the Eurasia Nubia plate boundary.
\end{abstract}

(c) 2014 Elsevier B.V. All rights reserved.

\section{Introduction}

The evolution of triple junctions (TJs) is a topic of major interest for plate tectonics and geodynamic reconstructions (e.g. Georgen and Lin, 2002; Georgen and Sankar, 2010). In oceanic settings, plate reconfiguration is generally inferred from available magnetic anomaly patterns of the seafloor. However, the mechanisms and the time over which a plate boundary changes its location remain poorly understood, especially in areas where oceanic spreading occurs at very slow rates (e.g. Vogt and Jung, 2004). The study of volcanism occurring close to such TJs offers a unique alternative to overtake these limitations and to constrain the interactions between mantle dynamics, regional deformation, melt production and migration in relation to plate boundary reconfiguration over short geological periods ( 12 Myr). The Azores volcanic province

\footnotetext{
* Corresponding author at: Univ Paris-Sud, Laboratoire GEOPS, UMR8148, Orsay, F91405, France. Tel.: +331691567 42; fax: + 33169154891.

E-mail address: anthony.hildenbrand@u-psud.fr (A. Hildenbrand).
}

in the North Atlantic is a target of particular interest for such purpose. The Azores archipelago comprises nine volcanic islands built during the Quaternary (except the easternmost Santa Maria Island) over an oceanic plateau encompassing the present-day TJ between America, Eurasia and Nubia lithospheric plates (Fig. 1). The origin of the volcanism in the Azores has long been attributed to plume ridge interactions (e.g. Cannat et al., 1999; Lourenço et al., 1998; Luís et al., 1994; Schilling, 1975; Searle, 1980; Vogt and Jung, 2004; White et al., 1976). The Azores plateau, especially, is generally interpreted as a large igneous province (LIP), formed during a plume-derived episode of enhanced melt production centered on the Mid-Atlantic Ridge (MAR) between 20 and 7 Ma ago (e.g. Cannat et al., 1999; Gente et al., 2003). The plateau roughly has a triangular shape, and is delimited in the south by the prominent East Azores Fracture Zone (EAFZ), a presently inactive transform zone interpreted as the fossil eastern branch of the Azores Triple Junction (ATJ). During the last few Myr, the plate boundary between Eurasia and Nubia has jumped to the Terceira Rift (TR), considered an active hyper-slow spreading oceanic rift (e.g. Vogt and Jung, 2004). The 